Kohl: a Journal for Body and Gender Research

Vol. 3, No. 1 (Summer 2017)

\title{
A Liberated Life? \\ Thoughts on the Paradoxical Binds of Queer Refuge
}

Hana Masri 
"Here I am, this successful gay lawyer living a liberated life. When someone comes forward saying there are gay people in trouble in other countries, how could I say no?"1 These words - spoken by Fred Hertz, a resident of San Francisco who, along with his partner, took in Subhi Nahas, a gay Syrian refugee - exemplify a common Western media narrative about the relationship between queerness and refugee status. Among the proliferation of compelling personal stories about the journeys many Syrians have undertaken in the wake of brutal civil war, testimonies of queer people fleeing not only political violence but persecution on the basis of sexuality and gender performance have become particularly prominent. ${ }^{2}$ Most, like Hertz, emphasize the freedom that queer Syrians experience once they achieve legal refugee status and are resettled in countries such as the United States and Canada. In these stories, such countries' openness toward queerness starkly contrasts descriptions of the Middle East, where "homosexuals are hunted down and subjected to barbaric torture."3 "To me, it felt like a jump twenty years into the future," states Danny Ramadan, a refugee who led the 2016 Vancouver pride parade, about his arrival to Canada. "Thank God l'm here," were the first thoughts of another gay Syrian man upon landing in Winnipeg. For Bassel Mcleash, who marched alongside Canadian Prime Minister Justin Trudeau in the Toronto pride parade, his experiences in Canada are described as "a jarring contrast to the life he had lived in Syria, where homosexuality is punishable by law." ${ }^{5}$

Such stories paint a sympathetic portrait of their subjects, presumably in an attempt to help Western audiences understand the particular struggles faced by queer people fleeing political violence and thus make those audiences more accepting of refugees. It remains crucial, moreover, to stringently address the very real anti-queer violences that exist to varying degrees in Middle Eastern countries at every level, from the interpersonal to the structural. Indeed, many of the refugees profiled in the articles I have cited do this kind of work with organizations in their own communities. However, there lurks a paradoxical - and much more sinister - potential behind narratives that offer Western nations as liberated safe havens for queer refugees; when such stories are painted with a brush coated in stereotypes, not only do they affirm historically violent (and inaccurate) understandings of "backward" Arabs who have not progressed enough to embrace sexual

\footnotetext{
${ }^{1}$ As quoted in Eli Wirtschafter, "Gay and Syrian: One Refugee's Journey to San Francisco," KALW: Local Public Radio December 12, 2016, accessed January 26, 2017. http://kalw.org/post/gay-and-syrian-one-refugee-s-journey-sanfrancisco\#stream/0

${ }^{2}$ Austin Grabish, "'Thank God I'm Here': Gay Syrian Finds Refuge in Winnipeg," CBC News January 4, 2017, accessed January 27, 2017. http://www.cbc.ca/news/canada/manitoba/gay-syrian-winnipeg-refugee-1.3918327; Ashifa Kassam, "Syrian Refugee Marches Beside Justin Trudeau in Canadian Pride Parade," The Guardian July 4, 2016, accessed January 27, 2017. https://www.theguardian.com/world/2016/jul/04/syrian-refugee-marches-beside-justin-trudeaucanada-pride-parade; Dan McDougall, "It Can't Get Any Worse Than Being Gay in Syria Today," October 17, 2015, accessed January 27, 2017. http://www.smh.com.au/good-weekend/it-cant-get-any-worse-than-being-gay-in-syriatoday-20151001-gize4o.html; Bradley Secker, "This Syrian Couple's Reunion Will Make You Believe In True Love," BuzzFeed September 13, 2016, accessed January 27, 2017; Czeslaw Walek, "The Only Hope for Gay Syrians is Refuge, But the Process is Painfully Slow," Alturi, accessed January 27, 2017. http://www.alturi.org/subhi_nahas_syria ${ }^{3}$ McDougall, "It Can't Get Any Worse."

4 Sarah Berman, "Meet the Gay Syrian Refugee Leading Vancouver's Pride Parade," Vice July 27, 2016, accessed January 27, 2017.

5 Kassam, "Syrian Refugee Marches."
} 
openness and diverse gender expressions, ${ }^{6}$ they also put all Syrian refugees at risk by bolstering the very same narratives that justify their inherent excludability from allegedly more progressive nations.

A devastating example of this paradox emerged in the U.S. context with Donald Trump's January 27, 2017 executive order titled "Protecting the Nation From Foreign Terrorist Entry Into the United States." In its justification for indefinitely blocking the entry of all Syrians and temporarily suspending the entry of people from Iraq, Iran, Sudan, Libya, Somalia, and Yemen, the order states:

The United States should not admit those who engage in acts of bigotry or hatred (including "honor" killings, other forms of violence against women, or the persecution of those who practice religions different from their own) or those who would oppress Americans of any race, gender, or sexual orientation. $^{7}$

Aside from the irony of using bigotry as a rationale to unfurl bigoted legislation, under the logic of this order all refugees from the Middle East and North Africa - particularly Syrians - become suspect. Even those who are themselves women or queer are swept up in the blanketing of every person from the seven countries included in the order as misogynistic, homophobic, and hateful, and therefore eminently excludable from the nation. Thus, while they emerge from different political orientations, the narrative arc of stories about queer Syrian refugees is much the same as that of Trump's executive order: the Middle East (without much differentiation between countries) is a "barbaric" place, one whose (assumed Muslim) people have not developed the same tolerance for difference as those in the U.S. In this way, even what appears to be supportive representation of refugees can ultimately undermine them when they seek asylum internationally. Testimonies like those presented in popular media, then, serve to buttress the same notions about the Middle East that result in discriminatory legislation against all refugees. Rather than opening up space for the acceptance of people fleeing violence, narratives about queer refugees reinforce some of the same rationales for erecting nationalist boundaries and rigorously policing them.

The idea that state institutions can use sexuality to determine entry to the nation in exclusionary, violent ways is, of course, nothing new. Scholars of queer migration, who examine the co-constitutive relationship between regulation of migration and regulation of sexuality and gender, have been making this same argument for many years. Lionel Cantú, Jr., for example, theorized in the early 2000's that "receiving asylum requires painting one's country in racialist, colonialist terms, while at the same time disavowing the United States' role in contributing to the oppressive conditions that one fled." ${ }^{\prime}$ While Cantú's work deals with migration primarily in the context of the U.S.-Mexican borderlands and relationship, his argument maps almost perfectly onto the contemporary situation of queer Syrians. Not only do their stories' emphasis on anti-queer violence in the

\footnotetext{
6 Joseph A. Massad, Desiring Arabs (Chicago: University of Chicago Press, 2007).

7 "Full Executive Order Text: Trump's Action Limiting Refugees Into the U.S." The New York Times January 27, 2017, accessed January 27, 2017.

8 Lionel Cantú Jr. with Eithne Luibhéid and Alexandra Minna Stern, "Well-Founded Fear: Political Asylum and the Boundaries of Sexual Identity in the U.S.-Mexico Borderlands," in Queer Migrations: Sexuality, U.S. Citizenship, and Border Crossings, eds. Eithne Lubhéid and Lionel Cantú Jr. (Minneapolis: University of Minnesota Press 2005), 61-2.
} 
Middle East uphold the notion of Western nations as the enlightened contrast to Syria's barbarism - in turn reinforcing the same narratives deployed to keep Syrians out - they also erase the role of the allegedly more progressive nations (especially the U.S.) in the political destabilization of the regions from which people are fleeing. ${ }^{9}$ In other words, an embrace of queerness as grounds for asylum requires the disavowal of racial or national identity in ways that uphold queers as the exception to otherwise valid systems of nationalistic violence, rather than condemning those violences in their entirety.

More recently, Jin Haritaworn has written about the ways that queers become desirable to the nation only in opposition to hateful Others, often understood as Muslim. Haritaworn writes that "bodies and populations constructed as 'Muslim' become repositories for sexism, homophobia, and anti-Semitism in ways that absolve white citizen subjects from responsibility for their violence and pave the way for more violence, now normalized as a social good." 10 In effect, queers become a tool for the nation, which expands its violences against those perceived Others under the guise of protecting vulnerable queerness. Trump's so-called "Muslim ban" operates exactly as Haritaworn describes; making a claim toward protection for "Americans of any race, gender, or sexual orientation," the executive order weaponizes queerness against Arabs and Muslims, with a total disregard for the anti-queer policies members of the Trump administration otherwise advocate. When queerness is deployed as part of a nationalist project, the intersectional experience of those who are both queer and Other - like the gay Syrian refugees profiled in Western media - become exceptions that are resolved on the backs of the very communities those refugees are a part of. The assertion of queerness in order to gain entry to the nation demands an extension of the logics that exclude whole populations based on their alleged hatefulness. Queers become an exception to the exclusionary rule and, despite their own refugee status, bolster the underlying assumption that refugees, and, indeed, migrants in general, deserve to be turned away.

That queers become acceptable exceptions for admittance to the nation is reflected in the process by which refugees are resettled through the United Nations. People asking for resettlement through the U.N. are expected to prove "well-founded fear of persecution for reasons of race, religion, nationality, political opinion, or membership in a particular social group." 11 The well-founded fear stipulation thus privileges individual attributes over the kind of general political conditions that create refugees. For this reason, many queer refugees, like Subhi Nahas, the man who was resettled in San Francisco, make their claims on the basis of being LGBT and therefore part of a particular persecuted social group that is recognized as such by the U.N. ${ }^{12}$ None of this is to say that people should not seek refuge through whatever means necessary, nor to deny that those who deploy these narratives for their own safety are escaping very real threats. However, it is absolutely crucial to scrutinize the broader implications of institutions' funneling of people in this way: the

\footnotetext{
9 Jon Sharman, "President Donald Trump is Bombing Four of the Seven Countries From Where He's Restricting Immigration," The Independent January 27, 2017, accessed January 28, 2017.

10 Jin Haritaworn, Queer Lovers and Hateful Others: Regenerating Violent Times and Places (Chicago: Pluto Press, 2015), 10

11 "What is a Refugee?" United Nations High Commissioner for Refugees 2017, accessed January 28, 2017. http://www.unrefugees.org/what-is-a-refugee/

12 Wirtschafter, "Gay and Syrian."
} 
resettlement of refugees primarily on the basis of queerness, rather than because they are fleeing violence that has killed hundreds of thousands, allows nations like the U.S. to skillfully sidestep any acknowledgement of the broader context that people are escaping and instead posit themselves as beneficent protectors of queer people, unlike those hateful, homophobic Others who deserve violent exclusion.

The paradox of queer refuge thus becomes clear: narratives in which queer Syrian refugees find liberation in the West both uphold the mythologized notion of countries like the U.S. and Canada as queer safe havens and, at the same time, reassert nationalist boundaries on the basis of an imagined backwardness of all other refugees. Queer claims to inclusion, when appropriated toward a nationalist vision, come with the hefty price of excluding some of the most vulnerable populations in the world. And, unlike claims that privilege the many at the expense of the few, emphasizing Syrian refugees' persecution on the basis of gender and sexuality obscures the broader political contexts that create refugees in the first place, instead favoring hyper individualized narratives that offer the West as a gracious savior of the few exceptions to the backward rule. In this way, not only do popular media narratives ignore Western participation in the conflicts that produce refugees in the first place, they also resolve the paradox of queer refuge by advocating for the acceptance of queers into the nation using the same logics that call for the rigid policing of borders against all Others. The possibility of being both queer and Other disappears, as disavowal of home country and culture becomes the condition for legal refugee status. We - especially those of us who exist in the crosshairs of queerness and Otherness - cannot, therefore, allow the nation's shallow embrace of queers to come at the expense of the lives of the rest. We must imagine otherwise, outside of narratives that weaponize queer exceptionalism at the expense of a great many. There is perhaps no better historical moment than now to continue that vital imaginative work. 